\title{
Desain Floating Resort sebagai Penunjang Pariwisata di Perairan Kepulauan Seribu
}

\author{
Alfian Ibnu Salim, Hasanudin \\ Jurusan Teknik Perkapalan, Fakultas Teknologi Kelautan, Institut Teknologi Sepuluh Nopember (ITS) \\ Jl. Arief Rahman Hakim, Surabaya 60111 Indonesia \\ e-mail: hasanudin@na.its.ac.id
}

\begin{abstract}
Abstrak - Kawasan Kepulauan Seribu berpotensi besar untuk dijadikan pengembangan wisata bahari mengingat letaknya yang dekat dengan ibu kota negara, yaitu DKI Jakarta. Beberapa pulau di kawasan Kepulauan Seribu pun telah dikembangkan menjadi tempat wisata. Jumlah kunjungan wisata setiap tahun terus meningkat. Pada tahun 2013 tercatat sebanyak 1,500,504 orang dan pada tahun 2014 tercatat sebanyak 3.030.639 orang. Namun, peningkatan jumlah wisatawan tidak diikuti dengan adanya peningkatan fasilitas penginapan sehingga beberapa wisatawan yang ingin menginap tidak mampu ditampung. Floating resort merupakan suatu gagasan desain bangunan terapung dengan lambung katamaran sebagai solusi untuk menunjang kegiatan pariwisata di perairan Kepulauan Seribu. Bentuk lambung katamaran memiliki beberapa keunggulan dibandingkan monohull terutama dari segi stabilitas yang bisa memengaruhi kenyamanan penumpang. Dalam mendapatkan ukuran utama desain floating resort ini dilakukan dengan metode penyelesaian lengkap total ship design element yang digabungkan dengan metode desain berdasarkan dimensi, luasan, dan volume ruang yang direncanakan. Selanjutnya dilakukan desain rencana garis dan rencana umum sebagai acuan untuk melakukan analisis teknis, seperti displacement dan berat kapal, stabilitas, dan perhitungan freeboard. Akhirnya didapatkan desain floating resort dengan payload 200 penumpang beserta 80 crew, serta ukuran

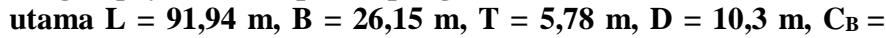
0,756. Setelah itu dilakukan analisis ekonomis sehingga didapatkan hsrgs floating resort sebesar Rp 18.969.539.711,08.
\end{abstract}

Kata Kunci-floating resort, katamaran, Kepulauan Seribu, pariwisata

\section{PENDAHULUAN}

$\mathrm{K}$ EPULAUAN Seribu merupakan salah satu kawasan wisata bahari dimana bentangan laut dan hamparan pulaunya sangat memesona. Kawasan ini pun menjadi salah satu destinasi yang banyak diminati oleh wisatawan baik lokal maupun asing. Kepulauan Seribu yang merupakan gugusan kepulauan terletak di sebelah utara Jakarta, tepat berhadapan dengan teluk Jakarta. Terdapat dua kecamatan di Kepulauan Seribu, yaitu Kecamatan Kepulauan Seribu Utara dan Kecamatan Kepualaun Seribu Selatan.

Kawasan Kepulauan Seribu berpotensi besar untuk dijadikan pengembangan wisata bahari mengingat letaknya yang dekat dengan ibu kota negara, yaitu DKI Jakarta. Panorama laut di wilayah ini menjadi daya tarik bagi wisatawan, terutama pada saat matahari terbit dan terbenam. Kondisi wilayah yang tenang serta asri dengan penampakkan air yang jernih menambah daya tarik bagi wisatawan.

Beberapa pulau di kawasan Kepulauan Seribu telah dikembangkan menjadi tempat wisata. Dari ratusan pulau yang berada di Kepulauan Seribu, tercatat ada 20 pulau yang telah dikembangkan sebagai pulau wisata. Berbagai sarana pariwisata seperti dermaga, anjungan pengunjung, restoran, dan pondok-pondok inap mendukung kawasan ini sebagai objek wisata yang berpotensi.

Jumlah kunjungan wisata setiap tahun terus meningkat. Pada tahun 2013 tercatat sebanyak 1.500 .504 orang dan pada tahun 2014 tercatat sebanyak 3.030.639 orang [1]. Keberadaan tempat peristirahatan sangat penting bagi wisatawan yang ingin menikmati keiindahan Kepulauan Seribu lebih lama sehingga tempat peristirahatan menjadi penunjang bagi perkembangan objek wisata Kepulauan Seribu. Tercatat sepanjang tahun 20132014 terdapat 278 home stay yang tersebar di berbagai pulau kawasan Kepualauan Seribu [1].

Seiring dengan terus meningkatnya jumlah wisatawan setiap tahun, maka perlu adanya fasilitas sarana yang memadai salah satunya yaitu penginapan. Lahan yang tersedia di pulau-pulau kawasan Kepulauan Seribu terbatas sedangkan permukaan air laut terus naik akibat dari efek pemanasan global. Untuk itu, dengan dirancangnya floating resort di kawasan Kepulauan Seribu bisa menunjang pariwisata di kawasan tersebut yang akan menjadi daya tarik bagi wisatawan baik nusantara maupun mancanegara.

\section{TINJAUAN PUSTAKA}

\section{A. Floating Resort}

Berdasarkan UU RI No. 17 Tahun 2008 Pasal 1 angka 36 tentang Pelayaran yang menyebutkan kapal adalah kendaraan air dengan bentuk dan jenis tertentu, yang digerakkan dengan tenaga angina, tenaga mekanik, energy lainnya, ditarik atau ditunda, termasuk kendaraan yang berdaya dukung dinamis, kendaraan di bawah permukaan air, serta alat apung dan bangunan terapung yang tidak berpindah-pindah.

Resort adalah suatu perubahan tempat tinggal untuk sementara bagi seseorang di luar tempat tinggalnya dengan tujuan antara lain untuk mendapatkan kesegaran jiwa dan raga serta hasrat ingin mengetahui sesuatu. Dapat juga dikaitkan dengan kepentingan yang berhubungan dengan kegiatan olah 
raga, kesehatan, konvensi, keagamaan serta keperluan usaha lainnya [2].

Resort adalah sebuah tempat menginap dimana mempunyai fasilitas khusus untuk kegiatan bersantai dan berolah raga seperti tennis, golf, spa, tracking, dan jogging, bagian concierge berpengalaman dan mengetahui betul lingkungan resor, bila ada tamu yang mau hitch-hiking berkeliling sambil menikmati keindahan alam sekitar resort ini [3].

Resort adalah sebuah kawasan yang terencana yang tidak hanya sekedar untuk menginap tetapi juga untuk istirahat dan rekreasi [4].

Resort Apung adalah tempat peristirahatan dan untuk relaksasi atau rekreasi yang menarik pengunjung untuk liburan atau menghabiskan waktu liburan yang berada diatas air dan tidak tenggelam serta jauh dari keramaian kota [5].

\section{B. Monohull}

Kapal memiliki banyak bentuk lambung yang disesuaikan dengan fungsinya salah satunya tipe mono hull, yaitu displacement hull, semi displacement hull, planning hull, dan semi planning hull dan juga dari jenis tersebut terdapat variasi bentuk antara lain: round bilge, hard chine, double chine seperti.

Displacement hull sangat sesuai untuk kapal yang mempunyai kecepatan rendah, kapal tersebut bergerak dipermukaan air seberat kapal itu sendiri. Displacement hull ini dibagi menjadi 2 macam, yaitu Heavy displacement dan Medium displacement.

Semi-displacement hull yaitu kapal yang bergerak pada permukaan air mendekati berat kapal itu sendiri dan pada kecepatan tertentu lambung bagian depan kapal terangkat sedangkan bagian buritan turun. Untuk mendapatkan kecepatan yang maksimal dengan stabilitas yang baik biasanya pada bagian haluan kapal berbentuk "V" dan pada bagian buritan berbentuk agak flat dan ada juga yang berbentuk agak round. Stabilitas saat kapal berhenti kurang nyaman dibandingkan tipe displacement hull.

Planning hull yaitu kapal yang bergerak di permukaan air dengan kecepatan tinggi sehingga air yang dipindahkan tidak seberat badan kapal itu sendiri karena sebagian lambung pada bagian depan terangkat sehingga hambatan di bawah permukaan air semakin kecil.

\section{Katamaran}

Katamaran merupakan kapal yang mempunyai dua lambung yang dihubungkan oleh geladak atau bridging platform di tengahnya. Karakter tahanan di air tenang tipe katamaran lebih besar dibandingkan dengan kapal monohull. Dominasi tahanan gesek dapat mencapai $40 \%$ dari tahanan total kecapatan rendah. Penurunan kecepatan akibat kondisi gelombang tinggi tidak dijumpai pada kasus katamaran. Kapal tipe ini dapat dioperasikan pada kecepatan yang relatif tinggi dengan konsumsi bahan bakar yang dapat diterima secara ekonomis dan kualitas seakeeping relatif baik untuk beroperasi pada kecepatan cepat antara 25-45 knot [6]. Katamaran memiliki beberapa kelebihan jika dibandingkan dengan kapal monohull, meliputi:
- Katamaran memiliki WSA yang lebih kecil dibandingkan monohull, tahanan gesek yang dihasilkan kapal katamaran lebih kecil, sehingga pada kecepatan yang sama, tenaga dorong yang dibutuhkan relatif lebih kecil.

- Luas geladak dari katamaran lebih luas dibandingkan dengan luas geladak kapal monohull.

- Stabilitas kapal lebih baik sehingga tingkat keamanan lebih tinggi.

- Sudut oleng relatif rendah $\left(0^{\circ}-8^{\circ}\right)$ sehingga meningkatkan rasa nyaman.

Namun, Katamaran juga memiliki beberapa kekurangan, meliputi:

- Teori dan standarisasi baik ukuran utama maupun perhitungan struktur masih minim mengingat katamaran merupakan teknologi yang tergolong baru.

- Teknik pembuatan yang lebih rumit, sehingga membutuhkan keterampilan yang khusus.

- Dengan memiliki dua lambung, maka kemampuan olah gerak kapal kurang baik apabila dibandingkan dengan kapal monohull.

D. Metode Penyelesaian Lengkap (Method of Complex Solution)

Dalam desain kapal ada beberapa metode yang dapat digunakan diantaranya metode optimisasi dan metode desain spiral. Pada metode optimisasi dilakukan iterasi satu tahap saja secara otomatis yaitu preliminary design sehingga menghasilkan solusi yang optimal dan waktu yang cepat. Metode spiral desain harus melewati beberapa tahap diantaranya, concept, contract, preliminary, dan detail design [7].

Metode penyelesaian lengkap jarang dipakai dalam perencanaan sebuah kapal kecuali jika digabungkan dengan metode yang lain. Pelaksanaan metode ini cukup rumit dan harus konsisten dalam mengerjakannya. Keuntungan metode ini adalah ketelitiannya cukup besar dan hampir tidak diperlukan koreksi dalam perencanaan, ulangan perencanaan seperti spiral desain tidak diperlukan dan penentuan harga dalam perencanaan dapat diketahui pada saat dini. Kekurangan metode ini adalah proses perhitungan sangat rumit dan memerlukan waktu yang relatif lebih lama dari metode yang lain.

Pada proses perencanaan, pengaturan dan pendiskripsian proses desain kapal, terdapat perbedaan anatara Level I (total ship) dan Level II (ship system) design (Harrington, 1975). Level I berhubungan dengan sintesa dan analisis dari atribut total kapal seperti bentuk lambung, rencana umum dan perkiraan atribut total kapal seperti berat dan titik berat. Sedangkan untuk Level II design berhubungan dengan sintesa dan analisis elemen utama kapal secara khusus seperti struktur, sistem penggerak (propulsi), pembangkit dan sistem distribusi listrik, ship control, navigasi dan sistem komunikasi dan sistem mekanik termasuk pipa dan HVAC (heating, ventilation dan air condition) serta outfitting. Beberapa hasil pada Level II design seperti data perhitungan berat, hambatan, kebutuhan awak kapal, biaya dan resiko merupakan input untuk Level I design. 


\section{METODOLOGI PENELITIAN}

Proses pengerjaan tugas akhir ini menggunakan metode pengerjaan dan analisis yang digambarkan pada diagram alir di bawah ini:

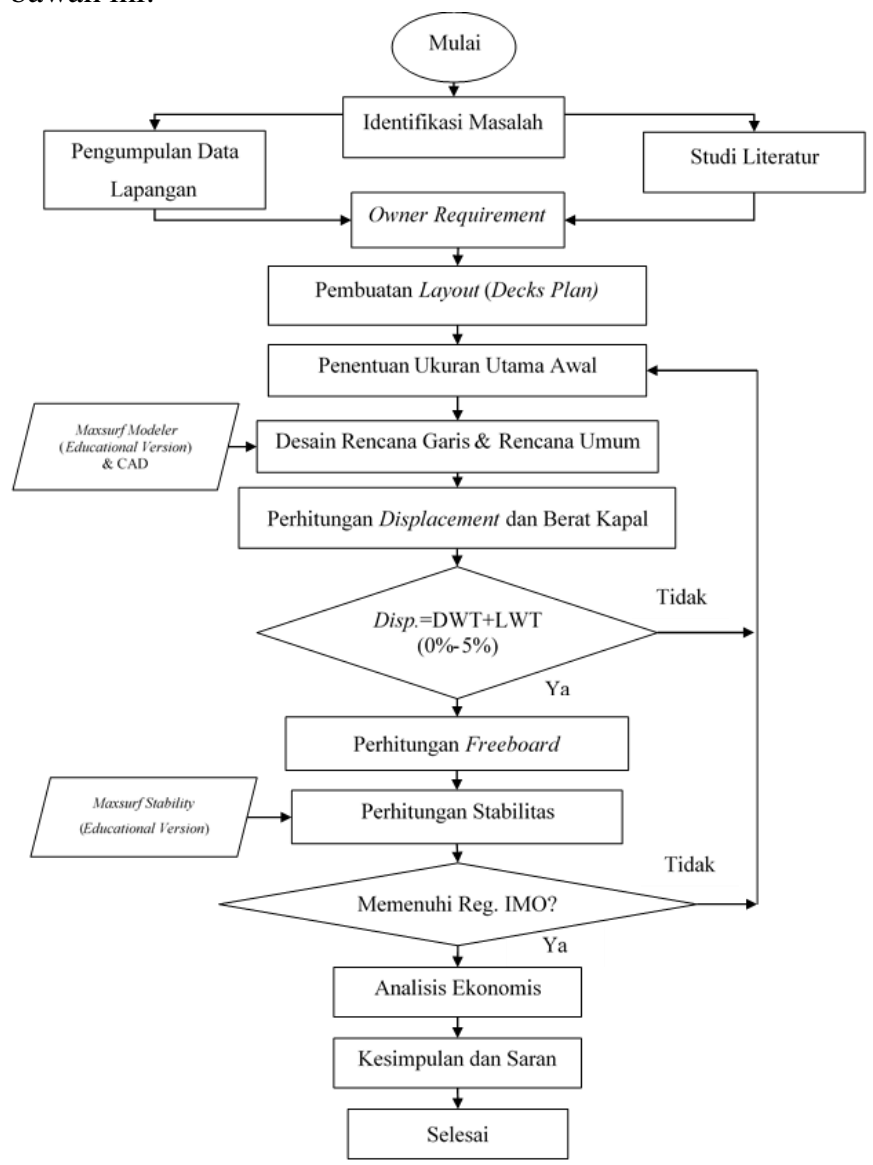

Gambar. 1. Diagram alir pengerjaan tugas akhir

\section{TINJAUAN DAERAH OPERASIONAL}

\section{A. Geografi Kepulauan Seribu}

Kepulauan Seribu yang terletak di Laut Jawa dan Teluk Jakarta merupakan suatu wilayah yang memiliki luas daratan hanya $8,76 \mathrm{Km}^{2}$ dengan luas lautan $6.997,50 \mathrm{Km}^{2}$. Secara umum keadaan laut mempunyai kedalaman yang berbeda-beda yaitu berkisar antara 0-40 meter. Wilayah ini merupakan gugusan pulau-pulau yang terdiri atas 110 pulau dengan 11 pulau diantaranya diperuntukkan untuk pemukiman penduduk.

Batas geografis Kepulauan Seribu: sebelah utara dengan Laut Jawa/Selat Sunda; sebelah timur dengan Laut Jawa; sebelah selatan dengan Kota Administrasi Jakarta Utara, Kota Administrasi Jakarta Barat dan Kabupaten Tangerang; dan sebelah barat dengan Laut Jawa/ Selat Sunda. Secara astronomi, terletak diantara $05^{\circ} 10^{\prime} 00^{\prime \prime}$ s/d $05^{\circ} 57^{\prime} 00^{\prime \prime}$ Lintang Selatan dan $106^{0} 19^{\prime} 30^{\prime \prime}$ s/d 106 $44^{\prime} 50^{\prime \prime}$ Bujur Timur.

\section{B. Klimatologi Kepulauan Seribu}

Keadaan iklim yang terjadi di perairan Kepulauan Seribu umumnya mempunyai dua musim nyata, yaitu musim hujan dan musim kemarau. Keadaan angin di Kepulauan Seribu sangat dipengaruhi oleh angin Monsoon yang secara garis besar dapat dibagi menjadi angin musim barat (Desember-Maret) dan angin musim timur (Juni-September). Tercatat kecepatan angin ratarata dalam tiga tahun terakhir (2011-2013) masing-masing yaitu 4,9 knot, 4,1 knot, dan 4,3 knot. Kecepatan angin tertinggi bisa mencapai 20 knot.

Arus laut dan pasang surut. Arus permukaan pada musim barat berkecepatan maksimum $0,5 \mathrm{~m} /$ detik dengan arah ke Timur sampai Tenggara. Pada musim timur kecepatan maksimumnya $0,5 \mathrm{~m} /$ detik. Gelombang laut mempunyai ketinggian antara 0,1-2,0 meter.

\section{Hotel dan Pariwisata}

Selama tahun 2014, Kepulauan Seribu dikunjungi oleh 3.030.639 wisatawan. Dari 13 pulau yang dikunjungi, Pulau Untung Jawa merupakan pulau terbanyak dikunjungi oleh wisatawan. Pulau Tidung adalah pulau yang paling banyak dikunjungi wisatawan mancanegara (wisman). Sedangkan Pulau Untung Jawa paling banyak dikunjungi wisatawan nusantara (wisnus). Pulau yang paling sedikit dikunjungi wisatawan adalah Pulau Macan. Tabel 1 merupakan data jumlah kunjungan wisatawan ke objek wisata unggulan, 20112014.

Tabel 1.

Jumlah kunjungan wisatawan ke objek wisata unggulan (Sumber: Sudin Pariwisata dan Kebudayaan Kab. Adm. Kepulauan Seribu)

\begin{tabular}{lrrr}
\hline \hline \multicolumn{1}{c}{ Objek Wisata } & Mancanegara & Nusantara & \multicolumn{1}{c}{ Total } \\
\hline P. Ayer (Resort) & 466 & 16.933 & 17.399 \\
P. Bidadari (Resort) & 451 & 24.703 & 25.154 \\
P. Kotok Tengah & 995 & 1.495 & 2.49 \\
(Resort) & & & \\
P. Sepa (Resort) & 947 & 2.703 & 3.65 \\
P. Putri (Resort) & 2.109 & 1.432 & 3.541 \\
P. Untung Jawa & 776 & 1.431 .119 & 1.431 .895 \\
P. Pramuka & 3.642 & 220.903 & 224.545 \\
P. Tidung & 4.283 & 582.78 & 587.063 \\
P. Harapan & 2.578 & 209.179 & 211.757 \\
P. Kelapa & 20 & 44.091 & 44.111 \\
P. Lancang & 4.48 & 472.132 & 476.612 \\
P. Macan (Resort) & - & - & - \\
P. Kotok (Resort) & - & - & - \\
P. Pelangi (Resort) & - & - & - \\
P. Antara (Resort) & 741 & 1.681 & 2.422 \\
Jumlah & 21.488 & 3.009 .151 & 3.030 .639 \\
2013 & 16.384 & 1.484 .120 & 1.500 .504 \\
2012 & 4.627 & 463.669 & 468.296 \\
$\mathbf{2 0 1 1}$ & 6.692 & 552.306 & 558.998 \\
\hline \hline
\end{tabular}

Selain itu, dari tahun ke tahun terjadi pertambahan jumlah homestay dan rumah makan, hingga tahun 2014 tercatat ada 278 homestay dan 56 rumah makan.

\section{ANALISIS TEKNIS}

\section{A. Owner Requirements}

1) Payload Floating Resort

Owner requirement didapat berdasarkan identifikasi masalah yang telah dilakukan. Salah satu owner requirement yang dimaksud yaitu payload. Payload dimaksud yaitu jumlah pengunjung/wisatawan di Kepulauan Seribu.

Berdasarkan data dari Badan Pusat Statistik Kabupaten Administrasi Kepulauan Seribu, jumlah wisatawan Kepulauan 
Seribu dari tahun 2011-2014 terus meningkat. Namun, hal tersebut tidak didukung dengan adanya peningkatan kapasitas penginapan. Hal itu dapat dilihat pada gambar 2 mengenai grafik pertumbuhan wisatawan dan kapasitas penginapan.

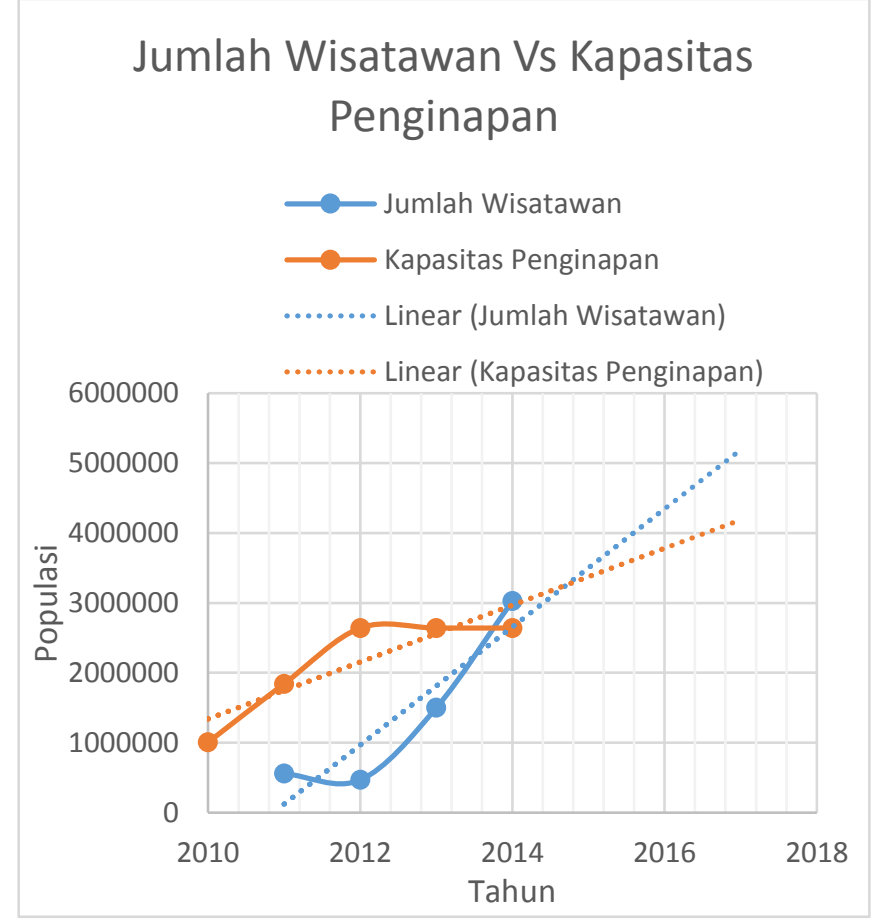

Gambar. 2. Grafik pertumbuhan wisatawan dan kapasitas penginapan

Dari data tersebut dilakukan peramalan (forecasting) hingga tahun 2017 menggunakan metode analisis regresi linier. Hasil peramalan menunjukkan jumlah wisatawan sepanjang tahun 2017 sebanyak 5.190 .617 orang. Diasumsikan jumlah wisatawan yang menginap di Kepulauan Seribu yaitu sebesar $70 \%$ dari total pengunjung sehingga potensi wisatawan yang akan menginap sebanyak 3.633 .432 orang. Sedangkan, hasil peramalan kapasitas penginapan pada tahun 2017 hanya dapat menampung 4.189 .032 orang. Dengan berasumsi adanya error factor sebesar $15 \%$ pada data tersebut, maka hasil perhitungan menunjukkan bahwa akan ada pertumbuhan penginapan pada tahun 2017 yang mampu menampung 3.560.677 orang.

Berdasarkan analisis di atas, jumlah penginapan yang ada belum mampu untuk menampung seluruh wisatawan yang akan menginap, yaitu sebanyak 72.755 orang. Artinya ada 199 orang per hari yang tidak tertampung. Untuk itu, dapat ditentukan payload kapal ini menampung 200 orang.

2) Penentuan Titik Lokasi Floating Resort

Payload floating resort ini adalah jumlah wisatawan sehingga hal tersebut akan dijadikan standar dalam penentuan titik lokasi floating resort. Pada tabel 1 tersaji data wisatawan yang berkunjung ke pulau-pulau di Kepulauan Seribu. Pulau Untung Jawa menjadi pulau yang paling banyak dikunjungi dengan total 1.431.895 wisatawan diikuti dengan Pulau Tidung dan Pulau Lancang dengan total masing-masing 587.063 dan 476.612 wisatawan. Berdasarkan analisis tersebut, maka ditentukan titik lokasi floating resort yang terlihat pada gambar 3.

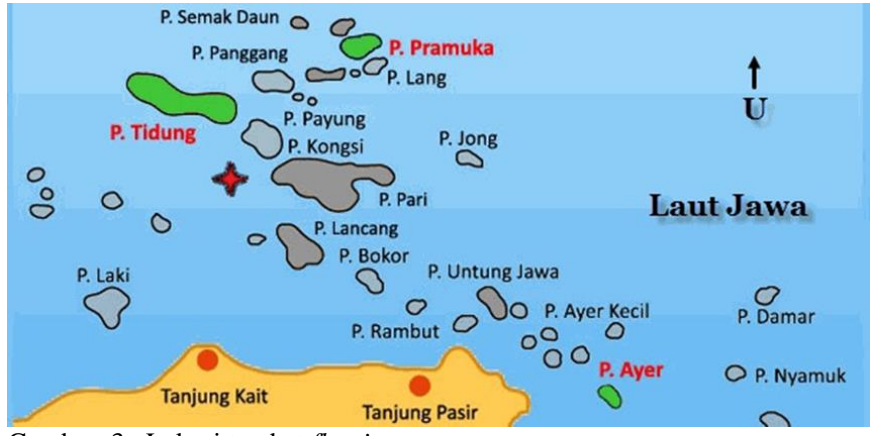

Gambar. 3. Lokasi tambat floating resort

\section{B. Analisis Jenis Lambung Kapal}

Setiap jenis lambung memiliki karakteristik yang berbeda sehingga memengaruhi performa kapal itu sendiri. Tabel 2 menunjukkan hasil analisis perbandingan jenis lambung kapal.

$$
\text { Tabel } 2 .
$$

Perbandingan jenis lambung kapal

\begin{tabular}{lcc}
\hline \hline & Monohull & Catamaran \\
\hline Stability & & $\sqrt{ }$ \\
Comfort & $\sqrt{ }$ & \\
Cost & $\sqrt{ }$ & $\sqrt{ }$ \\
Production Process & & $\sqrt{ }$ \\
Living Space & & \\
Safety & $\sqrt{ }$ & \\
Load Carrying Capacity & & \\
\hline \hline
\end{tabular}

\section{Layout Awal}

Pembuatan layout awal dilakukan dengan membuat rancangan ruang utama. Pembuatan layout awal mengacu pada standar volume, luasan, dan dimensi yang sudah banyak diterbitkan dalam bentuk buku, jurnal, paper, dll. Gambar 4 merupakan decks plan yang akan menjadi acuan untuk mendapatkan ukuran utama kapal.

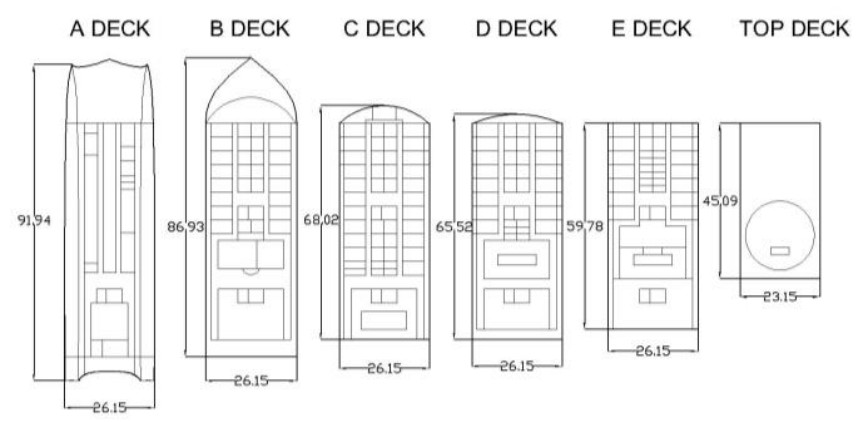

Gambar. 4. Decks plan floating resort

\section{Penentuan Ukuran Utama}

Lambung floating resort ini menggunakan jenis katamaran dengan dimensi utama yang disesuaikan dengan layout awal, yaitu:
- Panjang (L)
: $91,94 \mathrm{~m}$
- $\quad$ Lebar (B)
$: 26,15 \mathrm{~m}$
- $\quad$ Sarat (T)
$: 5,78 \mathrm{~m}$
- $\quad$ Tinggi (D)
$: 10,3 \mathrm{~m}$
- Block Coeficient $(\mathrm{Cb}) \quad: 0,756$
- $\quad$ Midship Coeficient $(\mathrm{Cm}) \quad$ : 0,954
- Waterplan Coeficient (Cw): 0,883 
- $\quad$ Prismatic Coeficient (Cp) : 0,793

- $\quad$ Displacement $(\Delta) \quad$ : 3417 ton

\section{E. Desain Rencana Garis dan Rencana Umum}

Pembuatan rencana garis dilakukan menggunakan software maxsurf modeler (educational version) dari model kapal yang sudah dibuat. Setelah model kapal sesuai dengan ukuran utama, didapatkan body plan yang merupakan potongan proyeksi dengan bidang-bidang vertical melintang, sheer plan yang merupakan potongan proyeksi dengan bidang-bidang vertical memanjang, half breadth plan yang merupakan potongan proyeksi dengan bidang-bidang horizontal. Gambar 5 merupakan desain lines plan dari floating resort.

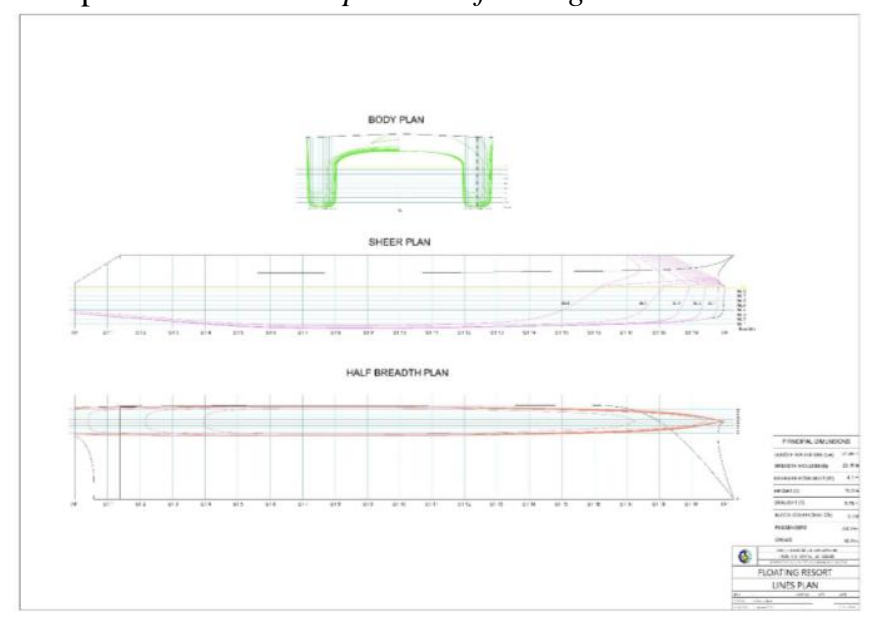

Gambar. 5. Rencana garis floating resort

Rencana umum dibuat menyesuaikan dengan rencana garis yang telah dibuat, kapasitas yang dibutuhkan, serta rencana geladak (decks plan) dimana luasan dan volumenya telah disesuaikan dengan ketentuan yang berlaku. Pembuatan rencana umum berfungsi sebagai dasar untuk membuat detail drawing. General arrangement (rencana umum) didefinisikan sebagai perencanaan ruangan yang dibutuhkan sesuai dengan fungsi dan perlengkapan kapal [3].

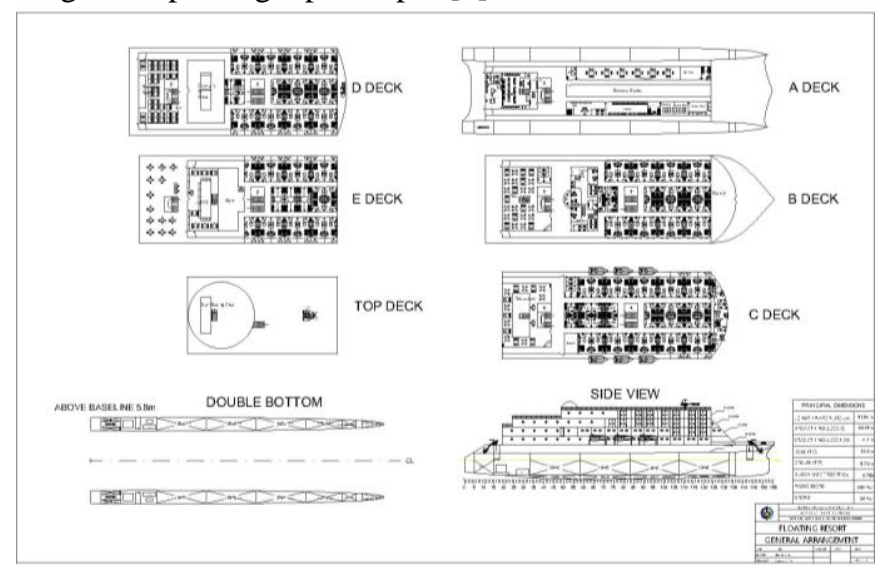

Gambar. 6. Rencana Umum floating resort

\section{F. Berat Floating Resort}

Dari rencana umum yang telah dibuat, maka dapat dilakukan perhitungan berat floating resort. Berat floating resort terdiri dari berat kosong/Light Weight Tonnes (LWT) dan berat mati/Dead Weight Tonnes (DWT).
- LWT : 1425,56 ton

- DWT : 1980,44 ton

- Total berat kapal : 3406 ton

Toleransi perbandingan antara displacement dengan berat kapal (LWT + DWT) adalah 0\% - 5\%.

- Selisih : 11 ton

- Margin : 0,3\% (memenuhi)

\section{G. Freeboard}

Dalam perhitungan freeboard floating resort ini mengacu pada International Convention on Load Lines, 1966, Protocol of 1988 Consolidated Edition 2005.

- $\quad$ Freeboard minimum : 0,34 m

- Actual freeboard :4,5 m (memenuhi)

\section{H. Stabilitas}

Dalam menghitung stabilitas floating resort dilakukan dengan bantuan software maxsurf stability advanced (educational version). Floating resort ini menggunakan kriteria nilai standar dari "Intact Stability (IS) Code, IMO" regulasi A.749 (18). Untuk standar sudut minimal saat nilai lengan GZ maksimal, digunakan IS code yang telah direvisi IMO mengenai kriteria untuk kapal multi-hull, yaitu HSC 2000 Annex 7 Muultihull.

Tabel 3.

Hasil analisis stabilitas floating resort

\begin{tabular}{|c|c|c|c|c|c|c|c|c|c|}
\hline \multirow{2}{*}{ No } & \multirow{2}{*}{ Criteria } & \multirow{2}{*}{ Value } & \multirow{2}{*}{ Unit } & \multicolumn{5}{|c|}{ Actual } & \multirow{2}{*}{ Status } \\
\hline & & & & $0 \%$ & $25 \%$ & $50 \%$ & $75 \%$ & $100 \%$ & \\
\hline 1 & Area $0-30$ & 0.055 & m.rad & 3.249 & 3.256 & 3.241 & 3.072 & 2.886 & pass \\
\hline 2 & Area $0-40$ & 0.09 & m.rad & 3.977 & 4.269 & 4.446 & 4.401 & 4.282 & pass \\
\hline 3 & Area $30-40$ & 0.03 & m.rad & 0.727 & 1.013 & 1.206 & 1.329 & 1.396 & pass \\
\hline 4 & $\begin{array}{l}\text { Max. GZ at } 30 \text { or } \\
\text { greater }\end{array}$ & 0.2 & $\mathrm{~m}$ & 5.284 & 6.75 & 7.736 & 8.309 & 8.569 & pass \\
\hline 5 & Angle of Max. GZ & & deg & 13.6 & 20 & 21.8 & 23.6 & 26.4 & pass \\
\hline 6 & Initial GMo & 0.15 & & 47.03 & 35.8 & 29.09 & 24.54 & 21.44 & pass \\
\hline 7 & Passenger Crowding & 10 & deg & 0.2 & 0.2 & 0.2 & 0.2 & 0.2 & pass \\
\hline
\end{tabular}

\section{ANALISIS EKONOMIS}

\section{A. Biaya Pembangunan}

Biaya pembangunan kapal pada umumnya terdiri dari, biaya berat baja seluruhnya, biaya perlengkapan kapal, dan biaya permesinan.

Tabel 4.

Biaya pembangunan floating resort

\begin{tabular}{|c|l|cr|}
\hline No & \multicolumn{1}{|c|}{ Item } & \multicolumn{2}{|c|}{ Value } \\
\hline 1 & Structural Costs & $\$$ & $605.004,95$ \\
\hline 2 & Mesin Bantu dan Pompa & $\$$ & $91.250,00$ \\
\hline 3 & Coating & $\$$ & $70.900,00$ \\
\hline 4 & Perpipaan dan Perlengkapan Listrik & $\$$ & $47.300,00$ \\
\hline 5 & $\begin{array}{l}\text { Perlengkapan Pemadam Kebakaran } \\
\text { dan Alat SAR }\end{array}$ & $\$$ & $33.241,71$ \\
\hline 6 & Radio dan Komunikasi & $\$$ & $3.531,00$ \\
\hline 7 & Equipment & $\$$ & $431.771,00$ \\
\hline 8 & $\begin{array}{l}\text { Jasa Galangan (10\% dari Structural } \\
\text { Costs) }\end{array}$ & $\$$ & $60.500,49$ \\
\hline 9 & Inflasi (4\%) & $\$$ & $51.319,95$ \\
\hline 10 & $\operatorname{PPn}(0 \%) \quad$ Total & - \\
\hline \multicolumn{2}{|c|}{$\$ 1.394 .819,10$} \\
\hline
\end{tabular}

Berdasarkan tabel 4 total biaya untuk pembangunan floating resort yaitu sebesar \$ 1.394.819,10 atau Rp 18.969.539.711,08 
dengan kurs yang didapat dari Bank Indonesia per 26 Mei 2016 adalah $1 \mathrm{USD}=\operatorname{Rp} 13.600,00$.

\section{B. Biaya Operasional}

Biaya operasional merupakan biaya yang harus dikeluarkan oleh pemilik kapal selama kapal tersenut beroperasi. Komponen biaya operasional yang harus dikeluarkan diantaranya, biaya perawatan kapal, asuransi, gaji crew kapal, cicilan pinjaman bank, serta biaya consumable.

Berdasarkan perhitungan pada tabel 5 , perkiraan biaya operasional yang harus dikeluarkan dalam 1 tahun yaitu sebesar Rp 7.503.428.155,00

Tabel 5.

Biaya operasional floating resort

\begin{tabular}{|c|c|c|c|c|c|}
\hline No & Biaya & & lai (Asumsi) & & Total \\
\hline \multicolumn{4}{|c|}{ Angsuran } & & \\
\hline 1 & Harga Kapal & & & $\mathrm{Rp}$ & $18,969,539,711$ \\
\hline 2 & Umur Ekonomis & & & \multicolumn{2}{|r|}{25 tahun } \\
\hline 3 & Depresiasi & & & $\mathrm{Rp}$ & $758,781,588$ \\
\hline 4 & Pinjaman dari bank & & $40 \%$ harga & $\mathrm{Rp}$ & $7,587,815,884.43$ \\
\hline 5 & Bunga bank & & $13.50 \%$ & $\mathrm{Rp}$ & $1,024,355,144$ \\
\hline 6 & Masa pinjaman & & & \multicolumn{2}{|r|}{10 tahun } \\
\hline 7 & Payments & & & \multicolumn{2}{|r|}{$1 \mathrm{kali} /$ tahun } \\
\hline 8 & Grace Period & & & \multicolumn{2}{|r|}{0 tahun } \\
\hline 10 & Angsuran Pokok & & & $\mathrm{Rp}$ & $758,781,588$ \\
\hline 11 & Bunga Angsuran & & & $\mathrm{Rp}$ & $667,628,989$ \\
\hline 12 & Angsuran Bank & & & $\mathrm{Rp}$ & $1,426,410,578$ \\
\hline \multicolumn{6}{|c|}{ Gaji Crew } \\
\hline 12 & Tingkat 1 (54 Orang) & $\mathrm{Rp}$ & $3,500,000$ & $\mathrm{Rp}$ & $189,000,000$ \\
\hline 13 & Tingkat 2 (16 Orang) & $\mathrm{Rp}$ & $5,000,000$ & $\mathrm{Rp}$ & $80,000,000$ \\
\hline 14 & Tingkat 3 (7 Orang) & $\mathrm{Rp}$ & $7,000,000$ & $\mathrm{Rp}$ & $49,000,000$ \\
\hline 15 & Tingkat 4 (3 Orang) & $\mathrm{Rp}$ & $10,000,000$ & $\mathrm{Rp}$ & $30,000,000$ \\
\hline \multicolumn{6}{|c|}{ Bahan Bakar } \\
\hline 16 & Harga per liter & $\mathrm{Rp}$ & 7,840 & $\mathrm{Rp}$ & 7,840 \\
\hline 17 & Pengeluaran per har & & 134 liter & $\mathrm{Rp}$ & $1,050,560$ \\
\hline \multicolumn{6}{|c|}{ Lain-lain } \\
\hline 18 & Biaya perawatan & & $10 \%$ per 5 tahun & $\mathrm{Rp}$ & $1,896,953,971$ \\
\hline 19 & Asuransi & & $2 \%$ & $\mathrm{Rp}$ & $379,390,794$ \\
\hline \multicolumn{6}{|c|}{ Rekapitulasi } \\
\hline No & Biaya & & Nilai & & Masa \\
\hline 1 & Angsuran & $\mathrm{Rp}$ & $2,185,192,166$ & pert & ahun \\
\hline 2 & Gaji Crew & $\mathrm{Rp}$ & $4,176,000,000$ & pert & ahun \\
\hline 3 & Bahan Bakar & $\mathrm{Rp}$ & $383,454,400$ & pert & ahun \\
\hline 4 & Lain-lain & & $758,781,588.44$ & & \\
\hline & Total & $\mathbf{R p}$ & $7,503,428,155$ & pert & ahun \\
\hline
\end{tabular}

\section{Nilai Investasi}

\section{1) Net Present Value}

Net Present Value (NPV) merupakan selisih antara pengeluaran dan pemasukan yang telah didiskon dengan menggunakan social opportunity cost of capital sebagai diskon faktor, atau dengan kata lain merupakan arus kas yang diperkirakan pada masa yang akan datang yang didiskontokan pada saat ini. Untuk menghitung NPV diperlukan data tentang perkiraan biaya investasi, biaya operasi, dan pemeliharaan serta perkiraan manfaat/benefit dari proyek yang direncanakan. Jadi perhitungan NPV mengandalkan pada teknik arus kas yang didiskontokan.

NPV yang didapat adalah Rp 117.075.177.711 dengan internal rate of return sebesar $16 \%$. NPV>0, maka investasi ini layak untuk dijalankan.

2) Break Event Point
Break event point (BEP) adalah sebuah titik dimana biaya atau pengeluaran dan pendapatan adalah seimbang sehingga tidak terdapat kerugian atau keuntungan. floating resort ini membutuhkan waktu 8 tahun untuk bisa kembali modal.

\section{KESIMPULAN}

Berdasarkan hasil perhitungan dan analisis, maka dapat disimpulkan beberapa hal, yaitu sebagai berikut:

1) Floating resort ini mampu menampung 200 pengunjung/tamu dengan jumlah crew sebanyak 80 orang.

2) Ukuran utama floating resort, yaitu:

- Panjang (L) : :91,94 m

- Lebar (B) : $26,15 \mathrm{~m}$

- $\quad$ Sarat (T) : $\quad: 78 \mathrm{~m}$

- Tinggi (D) : $10,3 \mathrm{~m}$

- Block Coeficient $(\mathrm{Cb})$ : 0,756

- Displacement $(\Delta) \quad$ : 3417 ton

3) Desain rencana garis dan rencana umum sesuia gambar 5 dan 6.

4) Floating resort ini mempunyai kelayakan investasi dengan detail sebagai berikut:

- Biaya kapal : : Rp 18.969.539.711,08

- Biaya operasional : $\quad$ Rp 7.503.428.155,00

- Net Present Value (NVP) : Rp 117.075.177.711

- Internal Rate of Return (IRR) : $16 \%$

- Break Event Point (BEP) : Tahun ke-8

\section{UCAPAN TERIMA KASIH}

Penulis Alfian Ibnu Salim mengucapkan rasa syukur dan terima kasih sebanyak-banyaknya atas doa dan dukungan dari orang tua. Penulis juga mengucapkan terima kasih sebanyakbanyak kepada Hasanudin, S.T., M.T. yang telah membimbing dalam menyelesaikan Jurnal ini. Selain itu tak lupa penulis sampaikan ucapan terima kasih kepada rekan-rekan Jurusan teknik Perkapalan yang telah menjadi kawan berjuang dalam menyelesaikan studi di perguruan tinggi.

\section{DAFTAR PUSTAKA}

[1] BPS Kab. Adm. Kepulauan Seribu, Statistik Daerah Kabupaten Kepulauan Seribu 2015, Jakarta: BPS Kabupaten Administrasi Kepulauan Seribu, 2015.

[2] Dirjen Pariwisata, "Pariwisata Tanah Air Indonesia, hal.13," 1998.

[3] N. S. Pendit, Ilmu Pariwisata, Jakarta: Akademi Pariwisata Trisakti, 1999.

[4] C. Y. Gee, Resort Development and Management, New York: WastonGuptil Publication, 1998.

[5] R. Novalina, Resort Apung di Karimunjawa, Semarang: Universitas Diponegoro, 2014.

[6] R. Taggart, Ship Design and Construction, New York: Society of Naval Architecture and Marine Engineer, 1980.

[7] Hasanuddin, "Desain Kapal LCU TNI-AL Menggunakan Metode Optimasi," Universitas Diponegoro, Semarang, 2015. 